\title{
DESCRIPTIONS OF VIRUS DISEASES OF PLANTS: CRITICISIVIS AND SUGGESTIONS
}

\author{
Melville T. Cook, Plant Pathologist, \\ Agricultural Experiment Station, Río Piedras, Puerto Rico
}

The work of the writer on the index of host plants of virus diseases and on the index of insect vectors of virus diseases of plants has brought to light a considerable number of incomplete and in some cases incorrect records in connection with virus diseases of plants. Most of these records were satisfactory at the time they were made but the lapse of time and the increase in the literature makes some of these early records rather obscure or indefinite. It is very doubtful if some of these records could have been made more definite or complete at the time the papers were writen but there is no reason for our continuing to make similar errors in the future.

Tobaceo mosaic was a satisfactory term until we found that there were several mosaic diseases of tobacco. It then became necessary to use a qualifying word such as "yellow mosaic", "interveinal mosaic", "aucuba mosaic", etc., and tobacco mosaic became "common tobacco mosaic". Our records would be much more satisfactory and much less likely to be misinterpreted in the future if the writers would insert qualifying terms before the names, even though it is a case of first virus disease reported on that particular host. Certainly the term "new virus disease" is unsatisfactory in all cases.

Records of new virus diseases of plants without definite names, numbers or letters and without descriptions of symptoms are not satisfactory and are likely to lead to confusion in the future. The term "new virus" is not satisfactory either now or in the future. A "new virus disease" today is an old virus disease tomorrow and another worker may present another "new virus disease" at any time in the future.

The use of the generic name of the host plant without the specific name is unsatisfactory. It is usually possible to secure the specific names except in the cases of cultivated varieties. In these cases. the scientific name of the host from which the variety was derived should be given if possible.

When common names of host plants are used, the scientific names. should be inserted in the titles, introductions or in parenthesis fol- 
lowing the common name. The peanut of most parts of the United States is "gruber" in some parts of the country and in many parts of the world it is "ground nut", but it is Arachis hypogea in all parts of the world. Common names of host plants should rarely, if ever, be used unless accompanied by the scientific names.

The same rule applies to the use of common names of insect vectors. The writer has found a considerable amount of confusion arising from the use of common names of insect vectors. The use of the terms "leaf hoppers" or "aphis" may mean very little without explanation in any part of the world except the locality in which it was writen. The writer has found that it is sometimes difficult to know whether two writers were referring to the same or two different insects. Common names of host plants and insect vectors may be satisfactory at the time and in the country in which a paper is writen but may be very unsatisfactory in the future and in other parts of the world.

Reprints should always carry the name of the publication in which they appeared and dates of publication. The paging should be the same as in the original publication. 